\title{
Second order pedagogy as an example of second order cybernetics
}

\section{Anne B. Reinertsen}

Nord-Trøndelag University College, Levanger, Norway

Corresponding address:

Anne B. Reinertsen

Department of Education, Høgskolen i Nord-Trøndelag, Postboks 2501, NO-7729, Steinkjer, Norway

Anne.b.reinertsen@hint.no

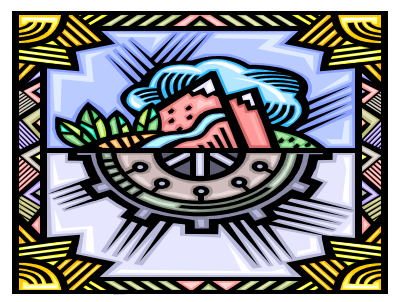

\section{Abstract}

This article is about seeing/creating/trying out an idea of pedagogy and pedagogical/ educational research in/as/with self-reflexive, circular and diffractive perspectives and about using second order cybernetics as thinking tool. It is a move away from traditional hypothesis driven activities and a move towards data driven pedagogies and research: Teachers, teacher researchers and researchers simultaneously producing and theorizing our practices and ourselves. Deleuzian becomings- eventually becomings with data - theory - theodata is pivotal. It is a move towards a Derridean bricolage. A different science of pedagogy operating as a circular science of self-reflexivity and diffraction in search of quality again and again and again: Theopractical becomings and inspiractionresearch.

\section{A Current Task for Cybernetics; an introduction and more}

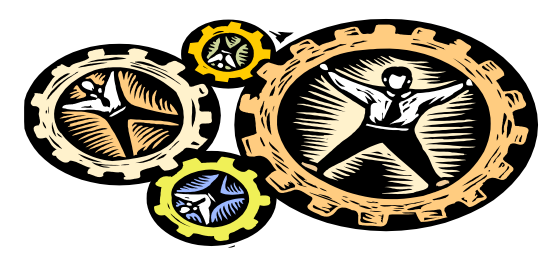

Second order cybernetics investigates the construction of models of cybernetic systems. It investigates cybernetics with the awareness that the investigators (read here teachers, teacher researchers, researchers) are part of the system, and of the importance inter alia of selfreferentiality, self-organizing and the subject/object relationship. Investigators of a system can never see its workings by standing on the outside because the investigators are always engaged cybernetically with the system being observed. That is; when investigators/ researchers observe a system, they affect and are affected by it. 
Using the "second order" idea for/in/with pedagogy and pedagogical/educational science and research would thus focus attention on the roles of the observer/teacher/teacher researcher/researcher and on reflexive phenomena such as the effect of theories on what is being studied. Further, on subjectivity processes and/or the creation of the/our/selves in/through/with complexity. Third, and with inspired always ... action research- thus inspiraction research processes in mind as we shall see; teachers performing research in/on their own practices together with researchers; all participants having to take part and be part of the same self-reflexive diffractive "as patterns of difference" (Barad, 2007, p.71) conduct: Teacher and researcher, teacher as researcher, teacher/researcher, researcher/teacher... Speaking of knowledge eventually through complexity and "uncontrollable becomings" (Deleuze \& Guatarri, 1987, p.278) that is. - And all of us.

In our (infused by possibilizing (data) technology) "technocultural" (Løvlie, 2003) society, the notions of "science" and "self" have gradually moved closer towards one another by producing a series of new semantic fields and novel links between them. These new recombinations of "self" and "science" have generated a wave of new self-centered or self-reflexive research fields. Self-reflexivity has become a pervasive feature in postmodern and poststructural thinking, in contemporary literature or in the artistic fields in general. Scholars, essayists or artists have become entangled with their/our products in a number of new forms and designs which help to promote self-reflexivity thus subjectivity as a virtuous and not as a vicious device.

The subject is seen as an effect of an event on a relational field: an assemblage of overlapping and intra-acting forces, not as autonomous, unitary and coherent. And again; a subject is thus a way of being in a state of continuous transformations and becomings. A subject is, - and must always be, made/done but again and again, or rather "undone" (St. Pierre, 2008): autonomous, unitary, coherent, but not. Subjective thinking and reflection in/through these approaches thus mean to intra-connect with something (data, theory...) and knowing is never done in isolation. Further and perhaps needless to say, but to avoid stepping back or holding the world at distance; reflexivity needs to be self-reflexive in relation to own seeing and thinking always. Designing me...you...data I am...tuning into I do...where we meet somewhere or not in cyber-/virtual-/space.

This article considers how the field of pedagogy and education might adopt the second order idea: An expansion of science; science two and /or research generation two. It requires a move beyond conventional, science one, constructivist philosophies of science directly or indirectly maintaining that scientific observations should be independent of the characteristics of the observer, and move toward self-reflexive and more critical and/or radical constructivist scientific approaches. Pedagogy and educational practices and research are composed of people who both observe and participate. Participants have thoughts, wills, dreams, biases and they/we change their/our minds. Theories, furthermore, not only describe the behaviour, (net) workings and wordings of social systems, when acted upon, they also change their/our functioning, (net)workings and again their/our wordings: Theory and practice, theory as practice, theory in practice, theory with practice theopractical... Theory and data, theory as data, theory in data, theory with data theodata... Action research and inspiration, action research as inspiration, action research in inspiration, and action research with inspiration, inspiractionresearch ... Becomings with theodata and theopractical.

Such pedagogies, sciences and research approaches might thus be called diffracted realfantast and experimentpoetic: Logic and argumentative, realistic and fantastic, experimental and poetic registers simultaneously at work always. They might be called constant theopractical theodata inspiractionresearch. They might span from creating experimental situations on the one side to perpetual critical societal- pedagogical - and cultural theoretical analyses aiming at developing a concrete historical understanding of social, pedagogical and cultural modes of presentations on the

\footnotetext{
${ }^{1}$ See below for explanations. And maybe you even would like to start reading there all together.
} 
other side. Deleuzian (1990, p.1) "aions"; infinitive time/future/past/

effect/event/instant/being/reason ... as "a pure becoming without measure" all over, and again; these concepts or words that we have to use or not - or "words" or words but not.

The way I see this, it is a move away from traditional hypothesis driven activities and a move towards data driven pedagogies and research and eventually moving to the "mythopoetic power of Bricolage" (Derrida, 1966) exploring the ability of language in a broad sense, to construct the very notion that there is a point of origin, or a centre, which the bricoleur can destroy, or from which bricolage may differ. Building on Derrida; Kincheloe, McLaren \& Steinberg (2011, p.168) describe the bricoleur you and me in this case; as "a handyman or handywoman who makes use of the tools available to complete a task" and moving about both researchers and teachers - again me/you - as "bricoleurs moving into the domain of complexity" (Ibid, p.168) exploring and destroying thus simultaneously possibilizing and securing, in my view, self-reflexive scientific, theoretical and methodological pluralism. It implies, and again the way I see this and suggest; putting data, theory and practice in a circular self-reflexive explore/destroy/possibilizing/securing relation and second order cybernetics might thus come in handy for us as bricoleurs to think with or as thinking tool.

This is ultimately a tribute to insecurity, resistance, difficulty.... and the questions we therefore can ask, the experiments we can try to investigate and an appeal to our imagination. Our goals - yours and mine- can thus preferably be thought of as being negative always in the sense that we - what about you? - all wish to become someone else or do something else than who we already are and what we already do. And to be honest, this implies working on the edge of competence and possible meanings only.

\section{Situated writing/speaking}

The situation I write/speak in - and to be perfectly clear: I regard writing/speaking as "interpretation" (thus in quotation marks) and part of the research process itself - is one in which we (in Norway at least) are discussing "theory dissolving in practice" (Abbott, 1988 in Skarpnes, 2011; Haug, 2011), are experiencing a felt distrust between the theory and the practice field regarding what they/we can do for each other, distrust between policymakers, theorists and practitioners, systemic reform fatigue and a severe scepticism towards research and the use of research based knowledge in schools (Reinertsen, 2009; Haug, 2011). Teachers often explain this through saying that theorists, knowledge institutions and researchers are not well enough informed about the challenges teachers face in their daily work. Further, that the knowledge they offer is not relevant. Even so, teachers, through the research field's growing uniformity (see below), are indirectly led to expect clear answers and general models and methods for how to do their work. When/if however they do not work (and nothing actually does more than once perhaps) this closes, in my view, discussions even further:

School administrator: "The fact is that schools and teachers do not trust anyone anymore. Politicians, researchers you name them. They say this, they say that. We however can only trust ourselves because we face students every day and we want to succeed, we want to contribute with the best we can. At least we try every day" (Field notes, June 2011).

However, after many years of conducting field work and doing research in/with teachers and schools, I am amazed by the tensions they work/live in and their wisdom, their openness and willingness to participate in knowledge creation processes and willingness to explore and ask critical questions to/about themselves but differently: Ask and be asked different questions, conduct different research and partake in producing different data. And to twist and turn it around: Ask/be asked/asking questions that are neither underestimating their abilities to speak through complexity nor overestimating their abilities to implement directly what a good theory, data, reform, policy or researcher say is best. Here I draw on extensive qualitative data from my PhD work (2004-2007) and 
from four different projects in four different municipalities the last five years (2007-2012), all with a focus on assessment and assessment literacy.

I thus suggest three issues we can problematize /questions we can ask ourselves together again and again in our circular, diffracted, self-reflexive and subjective endeavors:

- $\quad$ Speaking of knowledge through complexity, or perhaps; how to improve something or someone when/if something or someone cannot be systematized? Think for example about all the students we all have met who does not seem to "fit in".........

- $\quad$ Further, and with regard to histories of instrumentalist and reductionist forces in our systems; are the forces that make us abandon one type of theories, pedagogies and /or official policies as the main principle for building our pedagogical practises and research, in any way changed when/before/if we decide to try and/or build on another? Our answers should inform our further practices.

Finally, the question is how to build dynamics into- or inspire both research design and results in action research processes (- critical, participant, utopian, collaborative and/or self-study approaches) securing participants beliefs that they through their practices, have experienced something of value and thereby having the right to speak (write)? Cyberspace/place might be both an inspirational and ethical place to be... inspiractionresearch. Think about it as we go along.

This is important for increasing both rigour and relevance in educational research drawing on both quantitative and qualitative research approaches and more; participants being "empowered" both to choose between and judge the value of different types of research and its relevance to own practice. More or (here) new forms of science, includes exorbitant methods and extra-scientific domains, reflexivity and societal responsibilities, wild sides of societal self-organization and strange mechanisms due to critical complexity thresholds. Processes of looking for more than one answer; processes of looking for more. Hopefully I therefore succeed in discussing different possible takes on critical refunctioned self- reflexive action research approaches wherein "critical reflexivity" is operationalized "so that self-consciousness is not merely deployed as a critique of texts and stances after the fact, but is instead a part of the design and performance of action research (anthropological in the original) work from the beginning (Westbrook, 2008 in Denzin \& Lincoln, 2011, p.717). Second order pedagogy and research through second order cybernetics as thinking tool might be a place to start.

And to both theorize and explain a bit: This is ultimately about the dissimulation of the focus; the dissimulation of the cause effect relationship and working with unstable variables. Eventually, it is about designing me - and/through exploring "diffractive methodological strategies" (Barad, 1995, 2007; Haraway, 1997 in Hultman \& Lenz Taguchi, 2010) and a Deleuzian becoming with data - theory - and thus possible - or all sorts of performative me -ish - or rather "self-ish" research designs (Glanville, 2010). Discussing or rather increasing the amount of attention paid to the observer/ researcher in general lifting the subject position in both reform and research (Reinertsen, 2012). Focusing on the self, but not as One with. Not one or Two. Not One or the Many: "It is not a multiple derived from One, nor a multiple to which the One might be added (N+1). It is not made of units but of dimensions, or rather of shifting directions. It is neither beginning nor end, but always a middle, through which it pushes and overflows. It constitutes linear multiplicities in $n$ dimensions, without subject or object, which can be laid out on a plane of consistency and from which the One is always subtracted (n-1)" (Deleuze \& Guattari, 1983, p.47-58). Yup, and thinking more... uncontrollable rather I am just "I". It is an honest place/space to be/become.

\section{"Agenda"}


This article is thus both a preparation for- , and supporting working with new strategies in a postmodern and poststructural hybrid and multimodal pedagogical text universe. Obviously it is part of the discussion of the theory practice relationship but as in a theorypractice cloud of multiple, open, recombinative, wild, fragmented, non linear, non-trivial, eclectic, generative and simultaneous possibilities always. Decolonized and de -authorized knowledge production processes; theory and practice mutually challenging each other. It is a learning to live in tensions between and "betweenness" (Glanville, 2011): Complicated, complex and self-reflexive.

Second order pedagogy, second order pedagogical science and research is thus deeply embedded in a phase of transition within science, where cognitive distances are shrinking, and the cognitive, organizational and technological possibility and potential for inter- and transdisciplinary cooperation and learning is dramatically increasing. It is embedded in a phase of huge and rapid transitions within our societies, where inclusion, innovation and security are essential. - "progressing yet again", as we are "- to a society of creators and empathizers, pattern recognizers, and meaning makers" (Pink in Denzin \& Lincoln, 2011, p.715).

This is paradoxically a turning of pedagogy more to a scientific project and less ideological: A turning of both provisions and results, but as in preliminary always, into conditions for development and change. No research aiming at tracing mistakes or weaknesses nor any best practices, but through decolonized and nonauthoritarian critical, diffractive, self-reflexive thus inspiractionresearch approaches hopefully creating changes in own thinking about the use of- and the possibilities research might give. This is in my view, ultimately about turning schools into interesting workplaces for teachers and teachers to come: Workplaces in which pedagogy and pedagogical research is continuously discussed and challenged; teachers and students experimenting more, teachers and students daring more. Empowering teachers and schools and reducing skepticism towards research and science in/for reform and/or innovation. Own experiences and discussions with colleagues a really good place to start. Perhaps a way of thinking about this is as thinking with theory or a recycling of memories in/and learning. Further; discussions in teacher - teams about evaluation, assessment and quality: Teachers' and researchers', practitioners' and theoreticians' own translation and learning processes; very theoretical and very practical.

\section{Looking at binary; words and play}

As we go along you will probably detect severe tensions between words: Look for the dependent/independent relationship. Look for the user/producer, inclusion/exclusion, freedom/control and the individual/collective relationships. These come in addition to the theory/practice, theory/data and subject/object relations that you already have started to live. This is part of the game, part of the play, part of critical self- reflexive and diffractive inspiraction research approaches; the living in and with "cybernetic dynamic living research designs" (Müller, 2011) as we shall see. Through the focus on evaluation and assessment this can also be seen as being part of so called "transformative evaluation" (Dahler -Larsen, 2010, p.180). In this approach one works with and through mainly qualitative methodologies to strengthen a democratic conversation. However and hopefully obvious by now, I think working with quantitative methodologies to achieve the same is just as important. - Qualquantmixtative evaluation and assessment perhaps.

Taking account of the interaction between theories, self-reflexivity subsequently subjectivity, history of pedagogical ideas and effects or pedagogy in society could be called "second order science".

Expanding the genres of what counts as knowledge, both in terms of how it is acquired and how it is to be judged as valid or rather viable. Developing theories that encompasses also previous theories and describes their effects on a pedagogy could be called "second order pedagogy". I try.

Next I will write and speak more in/with/through the Norwegian situation and after that more in/with - and this time also about, second order pedagogies through second order cybernetics. Last I 
will write/say something about having fun or joy- and theory development. I write/speak in a messy - some might say unfocussed way. There are "lines of flights" all over (Deleuze \& Guattari, 1983, p. 10). Art. Poems. I create new words. I break rules of grammar, punctuation ... you name it. It is deliberate. In a meta- perhaps meta-meta perspective I think this is what this kind of research requires from me - us. Writing with open, second order scientific exploration through a stringent dramaturgy will in my view not serve our good intentions. New realities might be created through linguistic "mistakes". I am a bit worried about moorings. Together with my better half I have sailed along and across the Norwegian coastline every summer for years. Every night we must throw anchor and/or find a good, safe and nice harbour. I know the feeling of relief in the evening and that of leaving in the morning and planning to come back next year. ... - and all the other good, safe and nice harbours we therefore probably never will find. And dangers too... And I write/speak only of myself leaving authority all to you. Mourning pedagogy and research I do.

\section{Background and assumptions underlying pedagogy - a Norwegian example ${ }^{2}$}

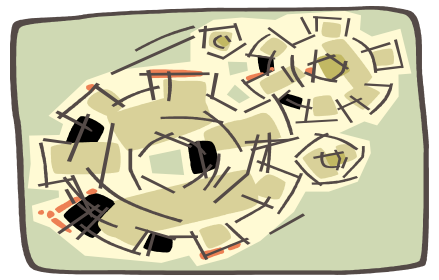

In Norway before the 1970s and -80s pedagogy was considered to be a theoretical and practical field in close relation to psychology and biology. Piaget's classical cognition theories were studied and used by theoreticians, universities, colleges and teacher trainers. Equilibrium theory related to learning was thus considered valid, assuming in a very brief way, that if a person (read here pupil/student/teacher) experienced disequilibrium due to not understanding something, the same person would through accommodating and assimilating new information actively restore or regain equilibrium, but now at a higher level. This in short was conceived of as learning and eventually knowledge production. Different maturity and/or ability stages were described. Behavioural studies were also conducted inspired and modelled by experimental psychologist B.F. Skinner focusing on reinforcement and operant conditioning. Self-regulation skills and problem solving capacities were considered universal elements in learning processes. Quantitative realist research approaches dominated, intended for both predication and control. Validity of - and reliability in the research processes itself were main control- or quality measurement approaches.

Gradually however, and through the 1980, 1990's and forward, pedagogy grew into becoming more of both a social- and to some extent ecological science. In addition to psychology and biology, economy, sociology, ethnography, eco- philosophy, broader social and leadership studies and gradually also cultural approaches were considered relevant. Sociocultural learning theories based on Vygotskyan and later also Bakhtinian perspectives increased the focus on the practice field and the importance of language mediation, contextualization, knowledge distribution and sharing of power in learning processes. Learning is now conceptualized as a process of internalizing new information through first outer and later (gradually) inner speech. Relational and situational competences

\footnotetext{
2 Now you could have started reading this article here. -starting with the concrete perhaps stuff that is. Flattening, avoiding hierarchies, hierarchical thinking is important. Authority issues are difficult:-). Becoming "situated speakers" (Richardson \& St.Pierre, 2005, p. 961) too... Around and around I circle... And remember I write...
} 
became principles for building practices. Scaffolding activities and proximal learning zones main buzzwords for directing or guiding practitioners (and students).

In this period, qualitative research approaches also "gained terrain" (Solbrekke \& Stafseng, 2009). Phenomenology, grounded theory, ethnography and case studies of "best practices" for example were believed first of all to be a way of describing, understanding and explaining practice but also a help and motivation for the practice field and hopefully lead to pedagogical improvements and culture change. Conducting research not so much for predication and control therefore, but assuming - or at least hoping, none the less that when these good examples were documented, others (read primarily teachers and schools) could learn from them. "Naturalistic generalization" (Stake \& Trumbull, 1982; Geerts, 1973; Conelly \& Clandinin, 1990; Lincoln \& Guba, 1985, 1979/2000; Guba \& Lincoln, 1989; Stake, 2005), triangulation and member checking quality measurement approaches. ${ }^{3}$ I have been there (Reinertsen, 1996).

Cognitive and sociocultural approaches to learning are both constructivist realist and conventional science one approaches, emphasising meaning making. Rational thinking and sharing of information as basis for knowledge production thus shared assumptions underlying pedagogy: Learning as a function of (positivist) activity in a broad sense. Teachers and even students are believed to be rational and/or professional users and beneficiaries of research and research results. Today constructivist quantitative and qualitative research approaches exist side by side. There are also examples of mixing the two assuming that this will mutually benefit, support and strengthen both research processes and the results that are produced.

\section{Doubts creeping upon me and mourning}

Indiscriminately almost we speak of this today as evidence and /or knowledge based research. Those who perform quantitative research tend to speak more of evidence though; qualitative researchers seem to like better the idea of results being knowledge based. I am not sure however that the differences between the two are felt by the users. Neither am I sure that society does ... I am not sure that the differences, similarities, strengths and weaknesses, possibilities and more are spoken of in a productive- as in complex way "empowering" (also in quotation marks remember) users to compare and contrast and encouraging the same users to speak and judge what different learning theories, different pedagogies, different research say and say not, if it is relevant or not, when, how and why. Again this is thinking of/about control - or quality measurements but as in viability through developing evaluation -and/or assessment literacy together with participants/teachers/users themselves (and me), aiming at higher levels of self-reflexivity in day-to-day practices and day-to-day research operations. - More about this below.

Norwegian action research projects have traditionally had a pragmatic approach and are also seen as constructivist processes. The more liberating and critical perspective of Carr \& Kemmis (1986), the critical, experimental and utopian approach of Nielsen \& Nielsen (2010), the empowerment and "criticalist"(s) move to the bricolage of Kincheloe, McLaren \& Steinberg (2011) and the self-study approaches of Pinnegar \& Hamilton (2009) and Tidwell, Heston and Fitzgerald (2009) are less used and underdeveloped: "Such perspectives are experienced by many as "rigid" and less pragmatic" (Furu, et al, 2007 in Gilje, 2010,p.12). Read on. ${ }^{4}$

\footnotetext{
${ }^{3}$ Read the Norwegian Journal of Pedagogy. Special issue celebrating the University of Oslo, institute of pedagogical research, for a more thorough historic account of one of the most influential pedagogical milieus in Norway (Norsk Pedagogisk Tidsskrift (NPT), 6/2009; Pedagogikkens stammer og territorier).

${ }^{4}$ What is this, a misunderstanding or a misconception? Politics perhaps ... I do not know, but something to speak more about - something to negotiate with - something to settle... but again.
} 
Further; in an organisational systemic perspective and school as a learning organisation, theory and practice development in Norway draw mainly upon developments in organisational psychology, organisational sociology and management theory (Senge, 1990). Also sociocultural "activity theory" has played a part (Engstrøm, 1999, 2001, 2004; Postholm, 2007; Postholm \& Moen, 2009). Lately development has been strongly influenced by the Reform Education Movement prominent in the $20^{\text {th }}$ century (Seashore, 2006) and by Public Management theory (Leithwood et al., 1999; Lillejord, 2003).

There have been several critiques of the rational choice theory of the school, with the researchbased argument that the institutional framework of the school as a social institution outweighs a one-dimensional emphasis upon rational choice and governance (none mentioned none forgotten). There have been several critiques of the rational choice theory of pedagogy and learning ultimately asking to turn pedagogy into a more humanistic, artistic and practical social science including also live poetic and/or praxis oriented modes of orientation. Praxis referring to a simultaneously practically, theoretically and philosophically infused field (Lather, 1986, 1993, 2004, 2007; St. Pierre, 2011). I eventually vacillated ashore here somewhere (Reinertsen, 2009).

Such critique is first of all due to a shortcoming of conventional constructivist research and rational choice theory of finding ways to handling fragmentation and subjectivity of the pedagogical field preventing therefore, the way I see this, the development of a language for complex and generative, pluralistic and living cross curricular and/or transdisciplinary theopractical research in pedagogy. Also too much weight is put on social aspects and interpersonal relations. Instead of including fragments and new dimensions always, fragmentation has been conceptualized as unscientific perhaps, bad and even dangerous and something one should avoid and work against (Reinertsen, 2009; Terum, 2009, 2010). The same goes for subjectivity and a fear of turning pedagogy into something personal or private only. In turn this might have led us into believing that complexity can be reduced by de facto ignoring both, resulting however in monotheorizing tendencies, possible blind spots - and then I mean blind spots - in our understandings and inequality.

\section{More reasons for my doubts and more mourning}

Socioconstructivist learning theories are however embraced by the majority of universities, colleges, researchers and teacher trainers in Norway today. There are thus tendencies of a growing uniformity in the field leading to singularity rather than inclusion and multiplicity (Haug, 2011). Universities, researchers and teacher trainers more or less speak the same language despite possible differences. Complexity issues and nuances are lost. Numbers and words seem to be/become the same. Research also tells us that pedagogy to a large extent has lost its role as a carrier of culture and its educative functions today (Karlsen \& Kvalbein, 2003; Reinertsen, 2009). Leaving pedagogy - and teachers - therefore unfortunately to some extent invisible and thus opening up "rooms that students in unclear manners fill up themselves" (Munthe \& Haug, 2010).

\footnotetext{
"I sometimes wonder what teachers do here actually "(Student at River High/ PhD Field notes).
}

"I have become no more that a cartoon figure. I might as well have home office" (Teacher at River High/PhD Field notes).

Further still, in spite of some mixing of methods, there is a huge gap between different research milieus. The division is still mirroring the old division between quantitative and qualitative research approaches often leading to polarizing, axiomatic, dichotomous, either/or, for and against crippling struggles of/for "terrain" between the two (NPT, 6/2009; Munthe \& Haug, 2010; Haug, 2011). In this way valuable findings and/or knowledge that we mutually could build on is lost. One reform effort is replacing the other with perhaps more negative than positive effects. The first report from; The 
Knowledge Promotion reform in which responsibility for own learning (in Norwegian called AFEL) was one of the pillars, tells us that the reform does not promote equality in achievement (Bakken, 2009). Issues related to inequality, hidden curricula, exclusion, and social class differences etc. that we thought we had dealt with in the 1970's are still there to be dealt with. And this in a situation in which two of our main buzzwords are dialogue and inclusive pedagogy. Today our focus is on autonomy in/and learning. Are the forces that made us abandon AFEL in any way changed ...?

to fit in...

- who did not seem

$$
\begin{aligned}
& \text { They are inflafed - the words - and emptied o the words - and need a filling up o the } \\
& \text { wards - by you - and me - the words.. }
\end{aligned}
$$

Norwegian research and policy has in the last decade, like many of its international counterparts, been motivated by a desire to alleviate disappointing performance in the international PISA tests (Kjærnslie et al., 2007). Interest in and forces wanting to use quantitative research to predict and control is growing again (Haug, 2010.). To prevent this from becoming a back and forth pendulum only, I think we - you and I - should work hard not to throw anything (read knowledge) away. We should work hard not to forget anything. Rather what I think we should do together is to work hard to make clear the conditions for any knowledge at any time, and thus why it works or not, if, how and when. Further we should always be prepared to add more fragments, dimensions and possibilities if necessary. That is if a child does not learn how to read and write through what we have done so far. This child and learning... This child and his/her particular abilities, talents, needs, wishes, feelings and dreams.... Learning perceived as both a function of activity and as poststructuralist diffèrance (Derrida, Deleuze, Barthes, de Mann etc). And again read on or start. Fly. Circle around. Stop.

- the words - by me - and you..

I fly: Innovation within neuroscience gives biological explanations concerning how our abilities to learn are influenced by our feelings (Zull, 2002 in Wilkinson \& Pickett, 2011, p. 158). We learn best in stimulating environments in which we feel confident of success. When we feel happy or confident, the brain exploits liberated dopamine. This strengthens our memory, attention and problem solving capacities. Also we exploit serotonin, which puts us in good humour or higher spirits, and adrenalin, which helps us do our best. When we feel threatened, helpless and stressed, our bodies are flooded by the hormone cortisol, which prevents both thinking and memory. Ultimately this is about inclusion and "Rights pedagogy" (NOU:18, 2009): Inequality in both society and school having a direct and detectable effect on the brain, on our ability to learn and our achievements. -Teachers, students, researchers all. It is one way of seeing things. Think about it. Discuss it. What does pedagogy say?

And I fly: I watched TV the other day: A teacher bringing her dog to school to teach Adrian to read. It worked marvels. Adrian said he felt so warm, relaxed and confident when Pixie slept in his lap. It took two weeks. ---- and thereby having the right to speak... Go on...

$$
\text { - the words - the feelings - by me - by you }
$$

\section{And therefore now even a poem perhaps abouf knowledge creation:}

There was biology and psychology

There was the social and sociology ... and against 
There was the quantitative

There came the qualitative ...

However; mixing is growing, and then came biology again

But differently

In the brain

And again :) and both against each other

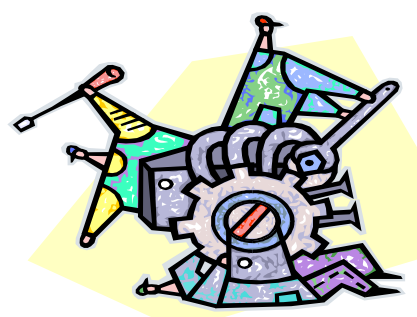

The gravity of the situation; stopping and starting point again

Resistance against and/or failure to take such critique and/or wishes and need to open up to complexity into serious consideration however has, in my view, resulted in a mutual disrespect and lack of trust and/or confidence in and between the practice - and the theory field; practitioners and theoreticians. -The producers and the users again, in a narrow sense. Teachers are therefore on the one hand often sceptical to the type of knowledge teacher trainers; colleges and universities wish to contribute with towards the practice field. They view their own experience and discussions with colleagues as more important for developing their own practices. Studies also do tell us that neither pedagogical theory nor evidence- and/or research based knowledge is used (Reinertsen, 2009; Haug, 2011).

When I am asked to give a lecture on a theme for teachers and administrators in schools, I am often met with questions indicating that they do not really believe that $I$ as a researcher and teacher trainer have anything to contribute. Teacher: "Can we trust what you say? You folks have said just the opposite before. Next year another researcher will come and say something else" (Field notes, February 2011). To add to the complexity and maybe irony of this; research also tells us that teacher trainers is a group of employees first and foremost preoccupied with practice, practice preparation and training (Gilje, 2010, p.6). Me that is :).

I think we have to take such scepticism seriously and/or try to untie the knot. I think we have to take a closer look at possible misunderstandings, mechanisms of oppression perhaps in our systems or what we at least might conceive of as lack of communication. Changes definitely occur on the basis of theories, policies, reforms and research, but I am not sure they necessarily are the ones we want or hope for. If the practice field does not get the knowledge it needs, or are rejected true participation in knowledge creating processes, it will be rejected. Referring again also to the issue of invisible pedagogies I think the task is urgent. For students, teachers, researchers, me, all ${ }^{5}$. At this point it is imperative however to avoid any blame traps. I think no normative finger pointing at and appeals of professional development will do. Neither will demands regarding implementation of evidence or research based knowledge. Predication and control won't work. Understanding and explaining practice in a conventional way won't do. Both ways indirectly or directly still maintaining independency between observer/observed, researcher/researched, producer/user, ultimately objectifying and instrumentalizing teachers, students and pedagogy alike.

This is thus both stop and starting point for rethinking and/or philosophizing diffractive pedagogies and research methodologies and/in learning and reform: Rethinking how they function, rethinking how they might function, rethinking refunctioned research methodologies and through - science two

\footnotetext{
${ }^{5}$ You? What do you think about this?
} 
- cybernetics. But to underline: This is no satirizing of conventional approaches, rather it is an attempt to build upon and extend into a recursive set of conversations and experiments, including their "ability" (Remember!) to guide us into "the mediations of guarded, packed, and traded elusive information" that serve to help us "understand the structure of the circuits as (well as) to challenge or guesstimate the veracity in the information packets" (Fisher, 2009 in Denzin \& Lincoln, 2011, p.717). Remember: not as One with. Not one or Two. Not One or the Many....

Again, the way I see this; what might work is to bring pedagogy and school to the alive and kicking mysteries, paradoxes and riddles in cyberspace: A cybernetic spaceplace - cloud - for everything and everyone and participants through this becoming subjects in their own learning processes: A process from a Foucaultian "subject of will", to becoming "subjects of thought" (Davies, 2010, p. 54-67). Becoming a "stranger" (!) that is within one's own language. Multilingualism within one's own language and the act of translating oneself into a culture of collaboration strengthening subjective judgment. Bricolage, Bricoleur, Bricolaying... Or twisting and turning it: The issue is to challenge presuppositions that inform the normalizing judgments one might make as a researcher/teacher (Kincheloe, McLaren \& Steinberg, 2011, p.172). Above I suggested three issues/questions we can think through. Read again.

If we continue not to take such critiques and scepticism into consideration, I think others will. I for one must admit that I find much interesting research about school in other fields than pedagogy today. See for example "School time" (Bjerrum Nielsen, 2009, my translation), "Liquidated. An Ethnography of Wall Street" (Ho, 2009), "Pictures of social class" (Dahlgren \& Ljunggren, 2010, my translation), "Justice" (Halsaa \& Helum, 2010) and as you already have seen; "The Spirit Level. Why Equality is Better for Everyone" (Wilkinson \& Pickett, 2011). Mourning pedagogy I am, this is.

$$
\begin{aligned}
& \text { In the brain } \\
& \text { And agaîn } \\
& \text { And daffecently } \\
& \text { Mulfà - plural fexts I am } \\
& \text { Think fanks and with ... } \\
& \text { Thinking fool l am }
\end{aligned}
$$

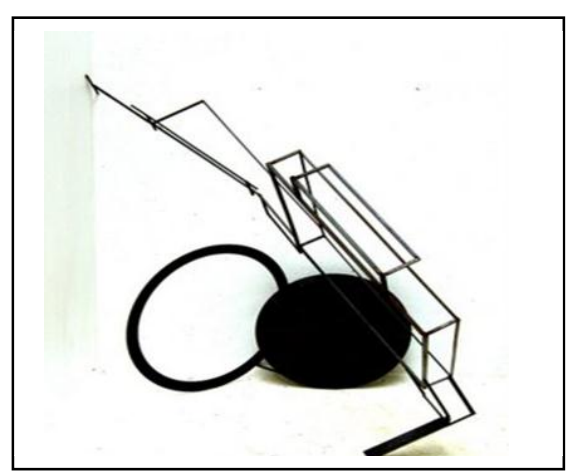

ECLIPSE 2001 Kjell Varvin: "I like to go where the systems break down and an increasing disorder takes place, where there is a great risk of losing control or of getting lost," says Kjell Varvin about his own working method. This may seem rather paradoxical, looking at the end result of this working process: precise drawings - twoand three-dimensional - which indicate an intellectual approach and which are of an analytically clear-cut, wellordered, and controlled character (Borgen, 2011). Complex yet simple I say: Drawings, welding, out in space teachers and schools. Perhaps welding is a metaphor to consider, and a three - dimensional pedagogy?

\section{Designing myself and becoming with theory -data - theodata:}

\section{Modelling second order pedagogy and the self - reflexive turn}

Currently, and to sum up a bit, pedagogy seems to be defined more by its methods and ideals than by subject matter perhaps, living as in complex reality, relevance and viability, or for example by 
what compensative pedagogical role to play. These are however, by no means new thoughts for or about pedagogy. Cyberspace is a space/place we have been in/with for years and will... There are bodies there.

What is new however is the strong focus on the self in/through/with complexity in research. And, as already indicated; the fact that all participants are having to take part and be part of the same selfreflexive diffractive conduct: teacher and researcher, teacher as researcher, teacher/researcher: Teachers ultimately seen as knowledge workers and as scholar teachers. Creating a new critical culture of school taking the form of a "think tank" that teaches students... and here I cite in full: "Critical teacher/researchers explore and attempt to interpret the learning processes that take place in their classrooms. "What are its psychological, sociological, and ideological effects?" they ask. Thus, critical scholar teachers research their own professional practice. With empowered scholar teacher working in schools, things begin to happen. The oppressive culture created in our schools by top down content standards, for example, is challenged. In service-staff development no longer takes the form of "this is what expert researchers found-now go implement it". Such staff development in the critical culture of schooling gives way to teachers who analyze and contemplate the power of each other's ideas. Thus the new critical culture of school takes on the form of a "think tank that teaches students", a learning community" (Kincheloe, McLaren \& Steinberg 2011, p.166).

But if these ideas, thoughts and devices are to be more broadly accepted, adopted and made practical or operational in reform in general and action research connections in particular, I think some modelling method will be "needed". ${ }^{6}$ What need to be modelled - but as in machined only, are the changes in point of view regarding reflexivity in general and subjectivity in particular, and the role of government and/in school reform. The most important role being to create conditions for teachers and schools to be wanting and able to trust, govern, control and/or steering themselves within given provisions: Putting theory -data - to work: Or again; teachers and schools learning from trying to simultaneously produce and theorize themselves and their own reform processes. Autonomy... The law being ourselves in our search for a Deleuze and Guattarian (1997) "vibrationcenter" of learning; creating, recreating and cocreating a "thinkingmachine" (Ibid.): Thinking back, thinking thorough thinking further.

Ultimately, this is what I believe second order cybernetics hence second order thinking might help us with. I think it is a way of reducing scepticism and improving ("'!!?) communication. Not easy, mind boggling perhaps, necessary and fun. It implies the use of pedagogical theories to manage school becoming part of pedagogy both formally and informally. Inspiring constant critical, liberating, uncertain, subjectivist, artistic, human and robust research processes: Comparing and contrasting, mixing and supporting (not). Theories as part of the control system of pedagogy would be a part of second order pedagogy and would be an example of reflexive theory. In the following section on modelling, I draw extensively on Müller (2011) and his work on the roads to a new science of cybernetics. As we go along, we can philosophize over possible inspiractionresearch methodologies. Inspire - to - me - action - I am - I do - research - inspired more always - you too? Inspiractionresearch you and I and again ...

\section{Second order cybernetics ${ }^{7}$}

Second order cybernetics, also known as the cybernetics of cybernetics, proposes that the observer should be included in the domain of observation; - the researcher being included in the domain of research. Derived from the Greek kybernetes, or "steersman", the term "cybernetics" first appeared in Antiquity with Plato, and in the $19^{\text {th }}$ century with Ampère, who saw it as the science of effective

\footnotetext{
6 Referring to Ericson (2011) I guess I probably should conceive of what I do here as "further efforts" along both postmodern and post structural lines $(-)$. It is a mix and an example only.

${ }^{7}$ I think I/you could have started reading/writing here too, remember?
} 
government. The concept was later revived and elaborated by the mathematician Norbert Wiener in his seminal 1948 book, whose title defined it as "Cybernetics, or the study of control and communication in the animal and the machine" (in Heylighen \& Joslyn, 2001). Today it is a frame of reference for modern computer science and furthermore an overall attempt to forge a transdisciplinary "systems science" and evolving "living research designs" (Müller, 2011).

There are three main interpretations of cybernetics (Asaro, 2010 in Umpleby, 2011). First, in the narrow view, cybernetics refers to feedback systems. This interpretation is common among those who work on artificial intelligence. Second, according to the internal view, cybernetics is associated with a subjectivist epistemology. Those committed to a realist epistemology view this line of research as a serious error. Third, according to a broad view, cybernetics can be thought of as a general theory of information and regulation similar to physics, a general theory of matter and energy. This paper thus takes the second view. Far from rejecting realism, but adding a human touch. Not rejecting the other two, but in this case dealing with them, as we have seen, primarily because of what I conceive of as this build in robust preparation for- and scientific notion of difficulty, uncertainty, incompleteness, circularity and indeterminacy possibilizing a turning of science and research into an open art of practical philosophizing or a human thinking machine or think tank - and assemblages of possibilities and dynamic designs.

Through second order cybernetics/thinking, the potential of self-reflexive forms of practices and research is thus increasing and characterized by an intrinsic turn towards their own domain of investigations or towards the practitioners/researchers themselves. Three main groups or approaches can be identified according to their different forms of self-relations. What they have in common is that they produce a re-entry into their operational domain. A re-entry of

- $\quad$ a domain $D$ into the domain $D$

- $\quad$ an observer Ob into her or his observations Ob

- $\quad$ an observer $\mathrm{Ob}$ and a domain $\mathrm{D}$ into the observer's domain $\mathrm{Ob}(\mathrm{D})$

Self-reflexivity thus exhibits several comparative advantages: Self-reflexivity moves both our practices and research processes to more complex levels because the self-reflexive turn is able to incorporate a new and additional element into the processes themselves. Further; by re-turning to previous results and operating with them the output gains a higher level of robustness. Third: Selfreflexivity, if embedded in appropriate designs, is capable to achieve higher degrees of innovation, due to the higher complexity levels and due to an increase in cognitive and social diversity within self-reflexive settings: "Self-reflexive research offers a high potential for more robust results on the one hand and for more complex and innovative scientific outputs on the other hand" (Müller, 2011, p. 78).

The three groups correspond to "three clusters of self-reflexive designs with a total number of fourteen different research trajectories" (Ibid., p. 79), and I add practices and theopractical again. There are seven different roads to re-entries in the first cluster. These are self-reflexive designs based on re-entries of a variable domain $D$ into a variable domain $D$ and on operations on both the already available and on the re-entered domain D. Thus, the first cluster consists of (1) re-entries of Modernization II-research into the period of Modernization II, (2) of scientific problem solutions in the past into the current domain of societal problems, (3) of mutual expectations of self and others into the domain of mutual expectations of self and others, (4) of concepts into their own conceptual domain, (5) of scientific disciplines into their own scientific discipline, (6) of theories into the domain of theories or (7) of research into the domain of research outputs. The three first roads are compatible with main requirements also for conventional realist science one sciences and approaches. From road four and onwards however we are seriously on the self-reflexive science generation two roads requiring empirically speaking new languages for observation, new forms of 
theory construction and new forms of research designs. Normatively speaking; requiring new forms of logic as new rules for validation or viability.

In the second cluster there are four roads characterized by the inclusion of observers/ investigator and reflects different aspects of the inclusion of observers/investigators in their domain of observation/investigation. The observer becomes a non-trivial element in the usual scientific operations. And to underline: This implies a shift from objectivity to observer-dependency and from self-reflexivity as an excluded domain to self-reflexivity as an admissible and necessary operation. The most elementary form of a re-entry of an observer in her or his domain of observation lies in the explicit recognition of the observer-dependency of practically every scientific statement.

In the third cluster there are three roads, which recombine the characteristic elements of the first, and the second cluster and leads to combine re-entries of the observer and her or his research outcomes into both areas of observer and research outcomes. The 14 roads or trajectories are both descriptive of - and directing toward engendering discussions about/in/of the pedagogical field and how we might model second order action research methodologies subsequently second order pedagogies. My "agenda" again is therefore not for neither teachers and schools nor researchers to walk all roads, but to give ourselves something to think with, consider and choose from in turning school into those think tanks that teaches students. These fourteen self-related research designs might thus again best be conceived of as a cloud of different "clockworks" (Ibid., p.111) which are highly context dependent and find their specific rhythms dependent on the number and especially on the interaction patterns of observing systems observing systems.

Further, the fourteen different forms of scientific self-reflexivity can be recombined into new forms as well. In principle, one can identify for each of the fourteen designs groups binary dimension: Selfreflective or non- self- reflective, self-infective and/or non-self-infective.... - self-designing designs and non-self designing designs. Large numbers of new self-reflexive recombination's, most of them still unexplored, can be undertaken, and based on the fourteen dimensions and trajectories described: Working as continuous clockwork clouds continuously. See appendix for more details.

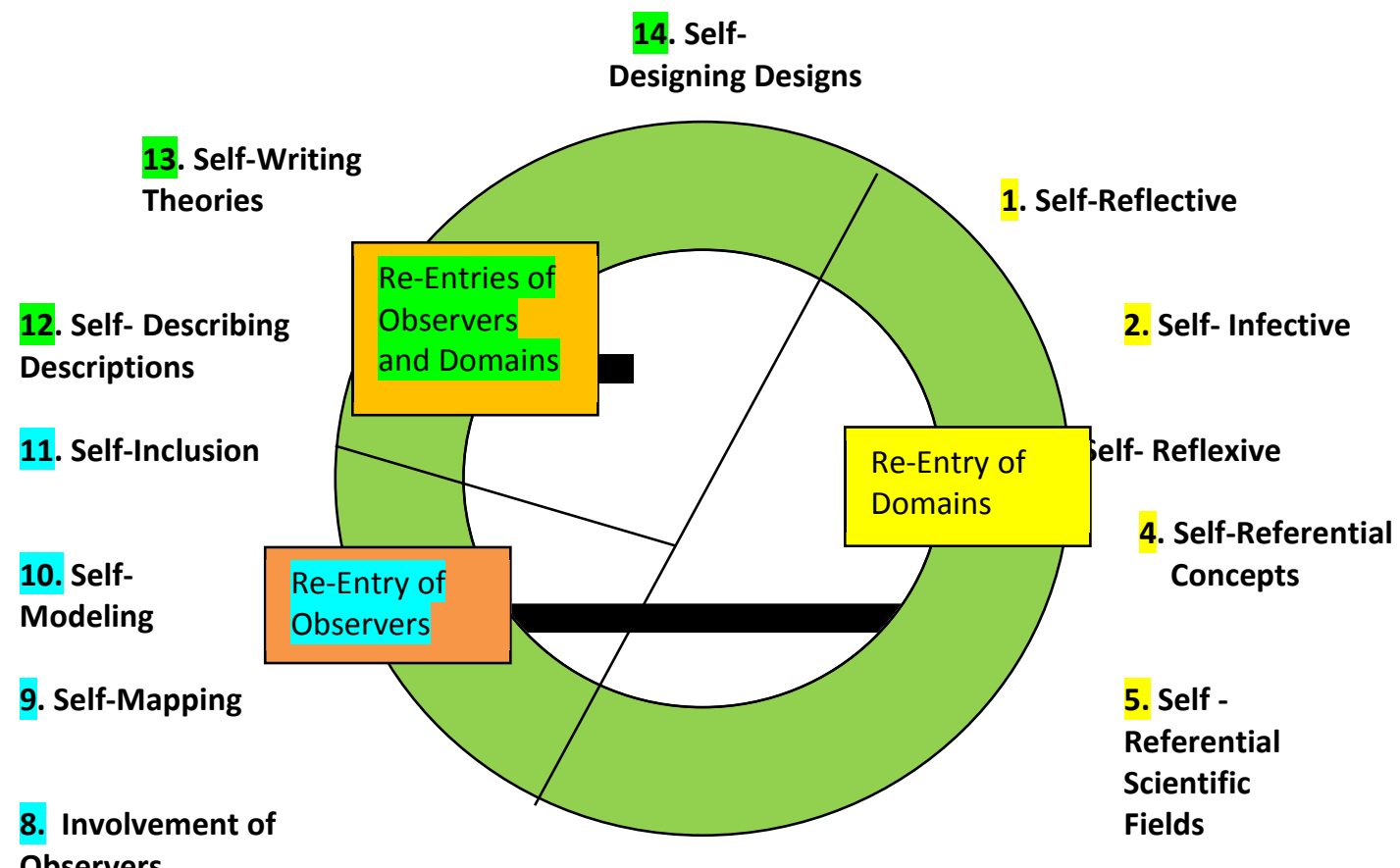

7. Self-

6. Self- Referential Theories

Referential Outputs 
And to elaborate a bit: Through self-reflexive clockwork cloud approaches teachers, teacher researchers, researchers and schools can put to work concepts that open up possibilities to understand what might emerge in material-discursive relational fields, where thus both human and non-human forces are equally at play in constituting student's - and own becomings: Human and non-human actors alike becoming "performative mutually intra-active agents" (Barad 2007, 2008 in Hultman and Lenz Taguchi, 2010). And again: Data and theory itself have a constitutive force working upon the teacher/researcher as much as the teacher/researcher works upon the data. Our thinking tool might thus prove itself useful.

\section{Outcomes and (re)presentation}

The clusters with re-entries into their justification contexts might produce both homogeneous and heterogeneous outcomes. In both empirical and normative approaches we might divide outcomes in two groups (Müller, 2011, p. 88-89): 1a) Empirical standardized research fields with high degrees of global diffusion and of global repetitions. The data-sources are homogeneous, consisting on sets of empirical test data and the scientific outcomes of scientific outcomes are usually characterized by features like a higher degree of robustness, validity, reliability or generality. 1b) Integration of various heterogeneous scientific outcomes from quantitative and qualitative outcomes is undertaken. 2a) Normative approaches and fields within the Philosophy of Science where philosophers operate on the general structure of actual scientific theories across different fields of science in order to improve them, on explanation schemes for different theory groups across scientific disciplines in order to develop requirements for explanation schemes in specific disciplinary settings, on evaluation criteria for hypotheses and theories across disciplines in order to specify transdisciplinary evaluation criteria etc. $2 \mathrm{~b}$ ) Complex forms of comparisons where scientific outputs are but one part in a much wider output class from traditional ways of world-views, world making or technical advances across different material and socio-cultural settings. This includes for example detection of biases inherent in the scientific method or towards more robust or more general principles of investigation.

Second order science and second order pedagogy demands new and other forms of representation or rather and again "representations" only. They might be open-ended multimodal and/or different forms of intertextual clockwork clouds representations. Compositions designed for and in moment. Genres created for unique purposes. Modal change is therefore possible ontological change (Kress, 2012) and a sign of a "Science in Action" (Latour, 1987). One could therefore initiate numerous approaches for writing together digitally or not: Mixing of genres, hybrids, mashups and cyborgs. Autoetnographies (Chang, 2008), duoethnographies (Norris et al, 2012), poetry (Faulkner, 2009), $D$ (erridean) D(elezian) D (eweyan) + Assemblages (Reinertsen, 2010) and around and around... Thinking back on the Norwegian example I hope we can start speaking/writing together. Data theory - driven all and self-assessing I hope.... In search for quality again and again and again we are. Let's discuss.

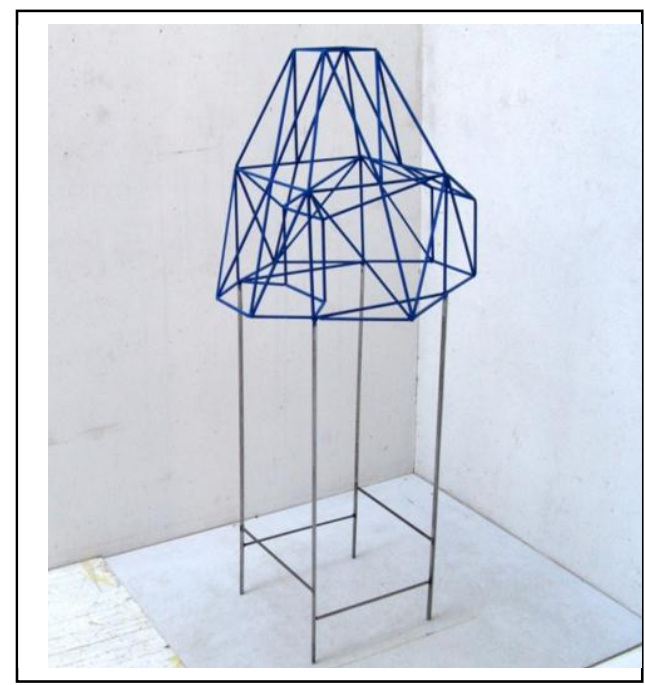

Reconceptualizing Educational Research Methodology 2012, 3(1)

\section{VESPIARY BLUE 2001 Kjell}

Varvin: 'I start each day's work without any preconceived idea or plan. In my studio anything can happen. Walls are crumbling and lines are flying off in all directions to join with other lines and patterns. My job is to catch resonant moments that exist for an instant within a vast interplay. I am aware of the speed and impermanence of existence and do not try to postpone the inevitable or prolong any illusion of stability. The resulting works exist briefly more as proposals than definite statements" (www. Kjell Varvin, 21th Oct. 2011). 


\section{Self - reflexive inspiraction research and fun; mourning still theory development}

"Without proclaiming a canonical and singular method, the critical bricolage allows the researcher to become participant and the participant to become researcher. By eschewing positivist approaches to both qualitative and quantitative research and refusing to cocoon research within the pod of unimethodological approaches, we believe critical theory and critical pedagogy continues to challenge regularly employed and obsessive approaches to research" (Kincheloe, McLaren \& Steinberg 2011, p. 173).

As we have seen; a reflexive domain is an arena where every element of the domain can be seen as a process and simultaneously a transformation of that domain. Every actor/participant/ observer/researcher is an actant and such domains are always open to the creation of new elements and new language. Each new element of the language stands for a process in the continuous creation of the domain: Every school, every teacher, every researcher, every team therefore an arena where every element is a process and simultaneously a transformation of that school, that teacher, researcher, that team... Every theory - data - theodata ... - an arena and a process of simultaneous possible transformation... The clockwork cloud of self-reflexive research as a tool and basis for discussing possible numerous critical, liberating, refunctioning, utopian self- reflexive inspiraction research approaches. Building on local strengths and wishes and any trajectory seen as a possibility.

By taking a stance that accepts and models self-reflexivity, we can examine the potentialities in these approaches but through clusters of barriers classified above as mysteries, paradoxes and riddles. The three groups of barriers can thus be seen bottom line, both as a strategy towards and a support for designing experimental procedures at all levels, and expanding our resonance rooms as practitioners. The way I see this, a way ultimately of turning science towards society and more fun - or again; perhaps Spinozian (go read it yourself $(-)$ ) inspired joy is the right word: See below. In the long run, it is a way of building trust and trust building. Accordingly, second order pedagogies (i.e. second order thinking within a special field) can be thought of as an example of second order cybernetics, an uncertain, subjectivist, human therefore and robust social scientific perspective.

It implies a working with forces and conditions when we look think and act. Looking to build pictures and gather information. Thinking to analyze and interpret and any description that works, for as long as it works. Acting as what we chose to enact and/or decide to do but again and again and again. Creating designs that are good enough and designing oneself - not perfect but unique - but again; good enough. This is much in accordance with creating everyday experimental, utopian and action oriented workshops or "free rooms" and the so-called adding of "more society" into local reflection processes that Nielsen \& Nielsen (2010, p.103-104) vividly describe. No motivation of others only inspiration. They also sum up:

Future-workshops and research-workshops are methodologically structured free rooms for strengthening of a critical utopian orientation and strange dialogues between different forms of science: critical theory as social praxis.

Critical utopian action research aim at social learning, which creates connections in everyday life and can be understood as a strengthening of something common in the field of research.

The researcher's role in action research is as committed to theoretical validity as to new forms of everyday "autonomous" practices (Ibid., p. 120). (My quotation marks. Just to remind me... you? ... us?...) 
Second order thinking might become a framework for freedom (if that is possible to say) and of participants/teachers/ researchers/me becoming less governed: Living research design inspired always - inspiring always - more: A nomadic stumbling and rhizomatic inquiry into our own practices. And remember: "Do it with joy and you are the "solution" "(Reinertsen, 2012). And referring to the appendix again: This article is perhaps an example of a trajectory 12- slightly 13 and a bit of a 14 approach and again and again and again. Emerging theopractical becomings and inspiractionresearch... And then there was this autonomy again as exactly what we want. - $A$ turning of both provisions and results... and a Rights Pedagogy.

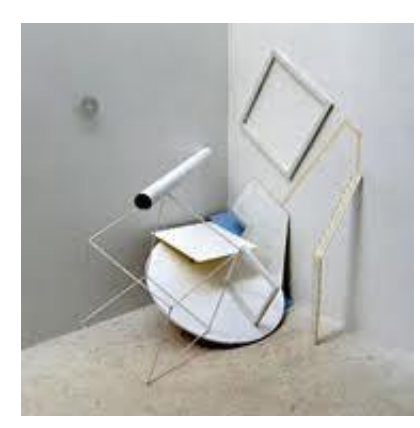

Kjell Varvin: UNSTABLE VARIABLE 2011

I am particularly interested in developing a way of experiencing the room. At stake is finding some correspondence between dimensions of one's own body in relation to the given environment. Not only physical proportions really, but also some sort of transcendental need to find its position in the room. One might think of a web of straight lines and dots stretching over enormous distances and which describe the concrete environment with coordinates as in three-dimensional maps. In this web one must find ones place and constitute a part of the whole. Every moment and every position is unique, everything happens in constant transformations, conditions change every second and make up moments of creation and decline, constantly and irreversibly. Perspectives are narrowed down to apply to the actual position and the actual moment. All existence is about this one thing, the intense experience of being present alive, active in a limited time span, the feeling of function and participation in an actuality. Transitoriness, the changing conditions under which one lives, abrupt or gradual transitions we all experience more or less intensely (www. Kjell Varvin (21th Oct. 2011, my translation).

\section{References}

Bakken, A. (2009). Prestasjonsforskjeller i kunnskapsløftets første år- kjønn, minoritetsstatus og foreldres utdanning. Nova - Norsk institutt for forskning om oppvekst, velferd og aldring. Oslo.

Barad, K. (2007). Meeting the universe halfway: quantum physics and the entanglement of matter and meaning. Durham: Duke University Press.

Bjerrum Nielsen, H. (2009). Skoletid . Oslo: Universitetsforlaget.

Borgen, T. (2011). Om å gå over streken. Essay i katalog til Kjell Varvins utstilling.

Carr, W. \& Kemmis, S. (1986). Becoming critical: education, knowledge, and action research. London: Falmer Press.

Chang, H. (2008). Autoethnography as method. Left Coast Press. California: Walnut Creek.

Connely, F. M. \& Clandinin, D. J. (1990). Stories of Experience and Narrative Inquiry. Educational Researcher. 5, 2-14.

Dahler-Larsen, P. (2010). Evaluering. In Brinkmann \& Tanggaard (Eds.), Kvalitative metoder, en grundbok (165-180). Viborg, Danmark: Hans Reitzels Forlag.

Dahlgren, K. \& Ljunggren, J. (2010). Klassebilder - Pictures of class. Oslo: Universitetsforlaget. 
Davies, B. (2010). The implications for qualitative research methodology of the struggle between the individualized subject of phenomenology and the emergent multiplicities of the poststructuralist subject: the problem of agency. Reconceptualizing Educational Research Methodology. 1(1), 54-68. http://www.rerm.hio.no

Deleuze, G. \& Guattari, F. (1983). On the Line: Rhizome. Semiotext(e) New York: Columbia University Press.

Deleuze, G. \& Guattari, F. (1987). A Thousand Plateaus. London: Athlone Press.

Deleuze, G. (1990). The Logic of Sense. Trans. M. Lester and C. Stivale, C.V. Boundas (ed.). New York: Columbia University Press.

Denzin, N. (2010). The Qualitative Manifesto. A Call to Arms. California: Left Coast Press.

Derrida, J. (1966). Structure, Sign, and Play in the Discourse of the Human Sciences. Writing and Difference. Trans. Alan Bass. London: Routledge.

Derrida, J. (1967/1976). Of Grammatology. Baltimore and London: The John Hopkins University Press.

Derrida J. (1994). Specters of Marx: The State of the Debt, the Work of Mourning, \& the New International. New York and London: Routledge.

Derrida, J. (2002). Who's afraid of philosophy? Right to Philosophy 1. California: Stanford University Press.

Engstrøm, Y. (1999). Activity Theory and Individual and Social Transformation. In Engstrom, Y. \& Miettinen, R. \& Punameki R. L. (Eds.) Perspectives on Activity Theory (19-37). New York: Cambridge University Press.

Engstrøm, Y. (2001). Expansive Learning at Work: Toward an Activity-Theoretical Reconceptualisation. Education and Work. 14(1), 133-156.

Engstrøm, Y., Toiviainen, H., Pasanen, A., Haavisto, V. (2004). Collaborative Concept Formation at Work. Paper presented in the Academy of management 2004 Annual Meeting "Creating Actionable Knowledge", August 6-1, New Orleans.

Erickson, F. (2011). A History of Qualitative Inquiry in Social and Educational Research. In Denzin \& Lincoln (Eds.) The SAGE Handbook of Qualitative Research. $4^{\text {th }}$. Edition (43-59). Thousand Oaks: Sage Publications. Inc.

Furu, E. M., Lund, T., \& Tiller, T. (2007). Action research: a Nordic perspective. Kristiansand: Høyskoleforlaget.

Faulkner, S. F. (2009). Poetry as method. Left Coast Press. California: Walnut Creek.

Gilje, $\emptyset$. (2010). Funn i praksis - Ny kunnskap fra 19 forskningsprosjekter i grunnopplæringen / praksisfou 1.utgave. Forskningsrådet.

Geertz, C. (1973). The Interpretations of Cultures. Basic Books: A Member of the Perseus Books Club. New York.

Geertz, C. (1988). Works and Lives: The anthropologist as author. Cambridge: Polity.

Geertz, C. (1993). Local knowledge: Further Essays in interpretative anthropology. London: Fontana. Glanville, R. (2010). Darkening the Black Box. Keynote speech at joint event of the collocated conferences of the $14^{\text {th }}$ World Multi-Conference on Systemics, Cybernetics and Informatics: WMSCI 2010. The $3^{\text {rd }}$ International Multi-Conference on Engineering and Technological Innovation: IMETI 2010. The $4^{\text {th }}$ International Multi - conference on Society, Cybernetics and Informatics: IMSCI 2010. Orlando, Florida.

Glanville, R. (2011). The Benefits of the Difficult. Keynote speech at joint event of the collocated conferences of the $15^{\text {th }}$ World Multi-Conference on Systemics, Cybernetics and Informatics: WMSCI 2011. The $4^{\text {rd }}$ International Multi-Conference on Engineering and Technological Innovation: IMETI 2011. The $5^{\text {th }}$ International Multi - conference on Society, Cybernetics and Informatics: IMSCI 2011. Orlando, Florida.

Guba, E. G. \& Lincoln, Y. S. (1989). Fourth Generation Evaluation. California: Sage Publications, Inc. Newbury Park.

Halsa, B. \& Hellum, A. (2010). Rettferdighet /Justice. Oslo: Universitetsforlaget.

Haug, P. (2011). Utdanning 2020 Konferanse "Teoribruk i utdanningsforskningen"- Mangfold eller 
ensretting. http://www.forskningsradet.no

Heylighen, F. \& Joslyn, C (2001). Cybernetics and Second-Order Cybernetics. In R. A. Meyers (Ed.)

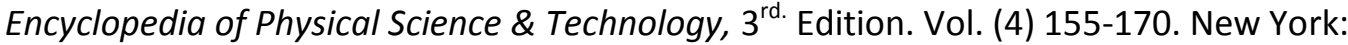
Academic Press.

Ho, K. (2009). Liquidated, an Ethnography of Wall Street. Durham and London: Duke University Press. Hodgson, J, Rønning, W., Skogvold, A. \& Tomlinson, P. (2010): På vei fra lærerplan til klasserom. (From Curriculum to Classroom) Report 3/2010. Bodø: Nordlandsforskning.

Hultman, K. \& Lenz Taguchi, H. (2010). Challenging anthropocentric analysis of visual data: a relational materialist methodological approach to educational research. International Journal of Qualitative Studies in Education. 23 (5), 525-542.

Pinnegar, S. and Hamilton, M. L. (2009). Self-Study of Practice as a Genre of Qualitative Research: Theory, Methodology, and Practice. Dordrecht Heidelberg London New York: Springer.

Karlsen, G. E. \& Kvalbein, I. A. (2003). Norsk lærerutdanning: søkelys på allmennlærerutdanningeni et reformperspektiv. Oslo: Universitetsforlaget.

Kaufman, L. (2007). Eigenforms - An Introduction. Paper presented at the 51. Annual meeting of the International Society for the Systems Sciences. Tokyo. August 5.

Kemmis, S. \& McTaggert, R. (2005). Participatory action research: Communicative research in the public sphere. In Denzin, N. \& Lincoln, Y. S. (Eds.) The SAGE Handbook of Qualitative Research $3^{\text {rd }}$. Edition (559-603). Thousand Oaks: Sage Publications Inc.

Kincheloe, J. L. (2003). Critical ontology: Visions of selfhood and curriculum JCT: Journal of Curriculum Theorizing. 19(1), 57-64.

Kincheloe, J. L., McLaren, P. \& Steinberg, S.R. (2011). Critical Pedagogy, and Qualitative Research: Moving to the Bricolage. In Denzin, N. \& Lincoln, Y. S. (Eds.) The SAGE Handbook of Qualitative Research $4^{\text {th }}$. Edition (163-177). Thousand Oaks: Sage Publications Inc.

Kjærnslie, M., Lie, S., Olsen, R., Røe, A. og Trumo, A. (2007). Tid for tunge løft. Norske elevers kompetanse i naturfag, lesing og matematikk i PISA (Time for PISA Endeavours. Norwegian Pupil's Competence in Science, Reading and Mathematics). Oslo: Universitetsforlaget .

Kress, G. (2012). Keynote lecture: Contemporary issues in educational studies and research. An exploration in the frame of a social semiotic multimodal theory of meaning-making: $10^{\text {th }}$ National conference on research in practice (FoU i Praksis) Trondheim, Norway.

Lather, P. (1986). Research as Praxis. Harvard Educational Review. 56(3), 257-277.

Lather, P. (1991). Getting Smart: Feminist Research and Pedagogy with/in the Postmodern. New York and London: Routledge.

Lather, P. (2000). Drawing the lines at Angels: Working the Ruins of Feminist Ethnography. In Pierre, Elizabeth A. and Pillow, Wanda S. (Eds.) Working the Ruins: Feminist Poststructural Theory and Methods in Education (284-311). New York and London: Routledge.

Lather, P. (2004). Applied Derrida: (Mis)Reading the work of mourning in educational research. In Derrida, Deconstruction and Education: Ethics of Pedagogy and Research (3-16). In Trifonas P.P. and Peters M.A. (Eds.). USA.UK. Australia: Blackwell Publishing.

Lather, P. (2007). Getting lost. Feminist Efforts Toward a Double(d) Science Albany: Suny Press.

Latour, B. (1987). Science in Action: How to Follow Scientists and Engineers through Society.

Cambridge, Ma.: Harvard University Press.

Law, J. (2004). After Method: Mess in social science research. London and New York: Routledge.

Løvlie, L. (2003). Teknokulturell danning. In Slagstad, R., Korsgaard, O., \& Løvlie L. (Eds.) Dannelsens forvandlingar (347-371). Oslo: Pax Forlag.

Leithwood, K., Jantzi, D. \& Steinbach, R. (1999). Changing Leadership for Changing Times. Buckingham: Open University Press.

Lillejord, S. (2003). Ledelse i en Lærende Skole (Leadership in a Learning school). Oslo: Universitetsforlaget. 
Lincoln Y. S. \& Denzin, N.K. (2011). Epilogue: Toward a "Refunctioned Ethnography". In Denzin, N. \& Lincoln, Y. S. (Eds.) The SAGE Handbook of Qualitative Research $4^{\text {th }}$. Edition (715-718). Thousand Oaks: Sage Publications. Inc.

Lincoln, Y. S. \& Guba, E.G. (1985). Naturalistic Inquiry. Beverly Hills, California: Sage Publications. Inc. Lincoln, Y. S. \& Guba, E.G. (2000). The only Generalisation is; There is no Generalization. (Org. 1979). In Gomm, R., Hammersley, M. \& Foster, P. (Eds.): Case Study Method, Key Issues, Key Texts (27-40). Thousand Oaks: Sage Publications, Inc.

Lyotard, J. F. (1984). The Postmodern Condition: A Report on Knowledge. Manchester: Manchester University Press.

Müller, K. H. (2010). From Science I to Science II: Major Changes in the Science Landscapes. Paper presented at joint event of the collocated conferences of the $14^{\text {th }}$ World MultiConference on Systemics, Cybernetics and Informatics: WMSCI 2010. The $3^{\text {rd }}$ International Multi-Conference on Engineering and Technological Innovation: IMETI 2010. The $4^{\text {th }}$ International Multi - conference on Society, Cybernetics and Informatics: IMSCI 2010. Orlando, Florida.

Müller, K. H. (2011). The New Science of Cybernetics; The Evolution of Living Research Designs.Vol.7 of the series: Complexity Design Society. Vienna: Edition echoraum.

Munthe, E., \& Haug, P. (2010). En integrert, profesjonsrettet og forskningsbasert grunnskolelærerutdanning. Norsk pedagogisk tidsskrift. 94 (3), 188 -202.

Nielsen, B. S. \& Nielsen K. A. (2010). Aktionsforskning . In Brinkmann \& Tanggaard (Eds.), Kvalitative metoder, en grundbok (97-120). Viborg, Danmark: Hans Reitzels Forlag,

Norris, J., Sawyer, R. D. \& Lund, D. E. (Eds.) (2012). Duoethnography: Dialogic Methods for Social, Health, and Educational Research (Developing Qualitative Inquiry). Walnut Creek, California: Left Coast Press.

Norges offentlige utredninger (2009).18: Rett til læring. (Right to learn).

Postholm, M. B. (2007). Interaktiv aksjonsforskning: forskere og praktikere i gjensidig bytteforhold. Forsk med!: lærere og forskere i læringsarbeid (12-33). Oslo: Damm.

Postholm, M. B., \& Moen, T. (2009). Forskningsogutviklingsarbeid i skolen: metodebok for lærere, studenter og forskere. Oslo: Universitetsforlaget.

Richardson, L. (1994). Writing: A method of Inquiry. In Denzin N. K. \& Lincoln., Y. S. (Eds.) Handbook of qualitative research (516-529). Thousand Oaks: Sage Publications Inc.

Richardson, L. (2000). Writing: A method of inquiry. In Denzin N. K. \& Lincoln Y. S. (Eds.) Handbook of qualitative research. $2^{\text {nd }}$. Edition (923-948). Thousand Oaks: Sage Publications Inc.

Richardson, L. \& St. Pierre, E. A. (2005). Writing: A Method of Inquiry. In Denzin, N. K. and Lincoln, Y. S. Handbook of Qualitative Research. $3^{\text {rd }}$. Edition (959-978). Thousand Oaks. Sage Publications Inc.

Reinertsen, A. B. (1996). Fagdidaktisk kunnskap i historie belyst gjennom undervisning i hendelsene på Eidsvoll I 1814. Tre kasusstudier av lærere i videregående skole. (Published Master Thesis). Tapir. Trondheim

Reinertsen, A. B (2009). SPUNK - A Love Story, Teacher community not; Writing towards a deauthorized and double(d) perspective of research and reform in schools. Published doctoral thesis. Beau Bassin Mauritius: VDM Verlag.

Reinertsen, A. (2012). Do it with joy, and you are the solution. Practical Philosophy as Conversations about Assessment in School. Journal of Policy Futures in Education. (Guest editors Dobson, S. \& Nordahl, T.). In press.

Senge, P. M. (1990). The Fifth Discipline. The Art and Practice of the Learning Organization. London: Random House.

Spivak, G. C. (1993). Outside in the Teaching Machine. New York and London: Routledge.

Skarpenes, O. (2011). Læreren-kunnskapen og moralen. Nordic Studies in Education. 31, 287-299.

Solbrekke, T. \& Stafseng, O. (2009). Pedagogikkens stammer og territorier. Norsk Pedagogisk Tidsskrift nr. 6. 
Stake, R. E. \& Trumbull, D. (1982). Naturalistic generalization. Review Journal of Philosophy and Social Science. 7(1), 1-12.

Stake, R. E.(2005). Qualitative Case Studies. In Denzin, N. K. and Lincoln, Y. S. (Eds.); Handbook of Qualitative Research. $3^{\text {rd }}$. Edition (443-466) Thousand Oaks: Sage Publications Inc.

St.Pierre, E. (2011). Post Qualitative Research: The Critique and the Coming After. In Denzin, N. \& Lincoln, Y. S. (Eds.) The SAGE Handbook of Qualitative Research 4. Edition (611-625). Thousand Oaks: Sage Publications Inc.

Tidwell, D., Heston, M. L.; Fitzgerald, L. M. (Eds.) (2009). Research Methods for the Self-Study of Practice. Dordrecht Heidelberg London New York: Springer.

Terum, L. I. (2009). Lærerollen og - utdanningen i støpeskjeen. Forskningspolitikk, nr. 1/18.02.

Terum, L. I. (2010). Når lærerutdannere blir kikket i kortene . In Gilje, Ø. Funn i Praksis: Ny kunnskap fra 19 forskningsprosjekter i grunnopplæringen (8-12). Foreløpig utgave. Forskningsrådet.

Umpleby, S. A. (2011). Second Order Economics as an Example of Second Order Cybernetics. Paper Prepared for a special issue of Cybernetics and Human Knowing. On the legacy of Heinz von Foerster. Washington DC, USA.

Umpleby, S. A. (2011). Second Order Science: Logic, Strategies, Methods. Keynote speech at joint event of the collocated conferences of the $15^{\text {th }}$ World Multi-Conference on Systemics, Cybernetics and Informatics: WMSCI 2011. The $4^{\text {rd }}$ International Multi-Conference on Engineering and Technological Innovation: IMETI 2011. The $5^{\text {th }}$ International Multi conference on Society, Cybernetics and Informatics: IMSCI 2011. Orlando, Florida.

Varvin, K. (1999, 2001, 2011). WESTERN SCULPTURE IN THE 20TH CENTURY by LU PINCHANG, Beijing ISBN 7-80580-556-3/J-519 page 56.

Wilkinson, R. \& Picket, K. (2010). The Spirit Level. Why Equality is Better for Everyone. Penguin Books. UK. Norwegian edition by Res Publica Oslo.

\section{Appendix}

Cluster one:

1. Self-Reflective design: A self-reflective science is a type of temporal parallelism and focuses on the phenomenology and on the dynamics of a new stage of modernity and is being produced during the rise of this new stage of modernity.

2. Scientific Self-Infection: Re-entries occur into the domain of societal problems and the re-entries are undertaken by scientific problem solutions from previous stages, which in the course of their implementation and their diffusion have become a source for contemporary societal problems themselves. Science is confronted with unintended consequences of its own expertise.

3. Mutual Self-Reflexivity as Re-Entries of Selves into the Self-Domain. This is a classical road and originates from a variety of areas like in history of philosophy, in theories of action or in applied fields like systemic or family therapy. The important point in a mutually self-reflexive configuration lies in the mutually self - reflexive entanglement between $A$ 's thinking of $B$ of $A$ and $B$ 's perspective of $A$ of $B$. The minimum of persons included is two, but it can also be extended to groups.

4. Re-Entries in the Conceptual Domain or Autology: This is based on the self-reference of theoretical concepts, and can be expressed in self-referential phrases like cybernetics of cybernetics, theories of theories, practices of practices, learning of learning and pedagogy of pedagogy and so on. Scientific concepts like communication, control, energy, space, time and others are capable of turning towards themselves for new semantic fields like the communication of communication, the control of control, the energy of energy, the space of space or the time of time. This brings about an operational closure in conceptual domains. Understanding will remain incomplete unless it is capable of understanding its own operations. Thus; to learn to learn, to teach to teach or to operate to operate requires a self referential twist into its own conceptual domain in order to reach completeness. "Teaching to teach, for example, turns out to be a central teaching operation and a pre-requirement in the education of 
future teachers. "Controlling controlling" becomes a highly demanding field in the science of control because it deals with a variety of core topics like the relationship between self-organization and control or the issues of controllability across different societal or natural ensembles "(Ibid: 84-85). This concept of self-reference can again be used for a re-entry in its own domain. Self-reference of selfreference generating self-reference again and again, round and round.

5. Re-Entries of Disciplinary Domains: Re-entries can be applied to all scientific fields like, as we have seen, sociology of sociology, system sciences of the systems sciences, philosophy of philosophy or pedagogy of pedagogy producing new domains of inquiry and closes scientific disciplines or a research field from a logical point of view. They may constitute inter- and trans-disciplinary fields in itself, and offer fresh insights for a domain that could be labeled as a "meta-theory of scientific knowledge" (Ibid: 86).

6. Re-Entries in the Theory domains: This can be expressed in the form of a theory of societal change of theories of societal changes, a theory of learning of theories of learning, a theory of pedagogy of theories of pedagogy and the like. Explorations within this design might offer a research trajectory towards more general and robust theories as we already have discussed above. Yielding more comprehensive and more abstract theoretical insights into domains of investigations.

7. The Re-Entry in the Domain of Scientific outcomes: These designs plays within the context of justification, operates on the outcomes of scientific research and comprises re-entries like scientific results of scientific results, tests of tests, outputs of outputs. These are "meta-analysis" generating a higher degree of robustness, confirmation and generality. "In principle one can take a series of explanations as scientific outputs and operate on in a recursive manner towards more homogeneity, towards ordering them in a morphological manner or towards complementarity relations" (Ibid:88). Four different groups of research designs can be distinguished: See Appendix B enclosed. In this connection we know from research (Hodgson et al, 2010) conducted on the implementation of the Norwegian Knowledge Promotion curriculum reform that Norwegian teachers offer feedback overwhelming on how to do a task without considering information about meta-cognitive learning processes. This is a Science 1 result possibilizing a designing of research operations re-entering theories about assessment and learning; a thinking with principals and oneself, teachers and researchers together. Participants thus operate on both first order and second order levels simultaneously: "second order operations operate on results of first order science operations recursively" (Ibid: 90).

\section{Cluster two:}

8. The Involvement of Observers. This has two meanings: First; observer dependency and involvement as contextualization and or as a transfer process. The move towards contextualization can be seen as one which leads from science as an accumulation of facts and theories to a widely distributed dynamic network of personal or subjective knowledge components which change mildly or wildly across spacetime contexts. The second direction for observer/investigator-dependence brings about a transfer of attributes of objects in an environment into the domain of the observer and her or his attributions. Transfer operations for the second form of observer involvement, is on the one hand about removing or de-constructing objects and, on the other hand, enriching, empowering or re-constructing observers. Reflexive grounded theory (Breuer, 2009 in Müller, 2011) is an example aiming to include the properties of the observer into the research process itself.

Related to pedagogy; this could be seen as a deconstructive rereading of the discursive archive of pedagogy to locate its institutional inclusions/exclusions, its ordering/disordering, its valuations/devaluations, and so on; a process of finding heterogeneity in its own corpus so to speak. This must precede a "reconstructive" phase(s) of the existing subdivisions configuring the disciplinarity of epistemological foundations, because a "critical re-elaboration of this hierarchy and of this problematic of hierarchy must not be restricted to new "theorems" in the same language (langage)" (Derrida, 1986 in Trifonas, 2000: 81). Trifonas continues: This "requires the heteroglossia of a fresh writing that inscribes and is inscribed by the rules of an unborrowed code following "another logic" (and here he refers to Derrida again), "one that can self-consciously evade the conceits of the metaphysical arrangements it is reacting to or may use in the performance of critique. This would 
presuppose: firstly, the inversion of the argumentative logics, the hierarchy of which privileges a normative arrangement of concepts from a binarization of terms (Good/bad, right/wrong, etc.); and, secondly, a displacement of the epistemological groundwork coordinating the ethical acceptance of the formal structuring of its concepts that organize the "essential" possibilities of thought itself" (Ibid: 81).

9. Self-Mappings or self-imaging: Here the I of an observer is confronted with a two-dimensional array with four quadrants. Self-related maps can be built with a number of different dimensions, which offer quite different perspectives of the observer who produces these images, by her/him-self. The horizontal dimension can be interpreted, for example, as degrees of personal acquaintances, ranging from "never met at all" up to "very frequent and very intensive personal contacts". The vertical dimension could be specified, for example, with respect to the relevance of an author's work in the pursuit of I's own research program. Thus, the vertical dimension has its lower limit at the point "no relevance at all" and its upper limit at "of highest relevance for l's own research work". As a consequence, the four quadrants cover the areas of high relevance/high degree of acquaintance, low relevance/high degree of acquaintance, low relevance/low degree of acquaintance and high relevance/low degree of acquaintance. Such self - related images could provide interesting basis for monitoring one-self in different dimensions across time.

10. Self-Modeling: Self-modeling can take place in a large number of different arenas and the modeling frameworks themselves can change from configurations of trivial self-inclusion to highly complex selfreflexive ones. Basically, three different forms of self-modeling can be distinguished. The first group can be labeled as self-inclusive where the model includes components and features, which are also shared by the observer of the model. In general, the trivial type of self-modeling occurs whenever a shared domain can be specified between the attributes of the observer and the features of the model itself and whenever the influence of the observer on the model dynamics remains negligible. The second model-group creates interactions between the observer and the model and qualifies as selfmodeling in the cognitive domain. A cognitive self-modeling application can be created for example, by focusing on a scientific discipline or sub-discipline and on a small number of theory groups in this particular domain. The observer enters into cognitive relations with the model because the model produces different scenarios on the future of the different paradigm groups which in turn, could lead the observer to change his/her paradigm and so on... The third and most complex form of selfmodeling, deal with basic problems of action, perception and cognition in societal problems and with the intricacies of individual and collective actions and their special forms of aggregations (Müller, 2011:98 building on the works of George Soros and Heinz von Foerster). Actors described by two functions, namely by a driving function for his/her operations and by a state function for his/her internal cognitive state: Actors as self-related by design, i.e., determined by her/his internal states. The cognitive function captures the relation between the cognitive evaluations and perspectives of a micro-actor and the macro-configuration and its information set. The macro-configuration in turn, is permanently produced and reproduced through the operations of a large number of micro-actors.

11. Self-Inclusion: The eleventh road towards self-reflexive sciences is based on the re-entry of attributes of observers into the domain of observers and the content of their cognitive operations. In particular, the theories, generated by observers, should include those attributes of observers that are necessary in order to generate or to produce these theory outcomes (Ibid: 101).

Cluster three:

12. Self-Describing Description: The twelfth road of self-reflexive approaches is linked with the operations of self-observation, self-awareness and with strong self-referential descriptions. Here, a description D is produced in a sequence of descriptive operations which describe the production process of the description D. Self-describing descriptions start from the description of initial conditions, including a set of goals which are to be reached in the context of the description. From here on the describer provides a description of the operations, which lead her/him from the initial conditions to the goal domain, which has been described at the outset. It might seem that such a research design leads, by necessity, to sketches for direct auto-biographical accounts only, writing about writing within a fixed context. But one can find several interesting research paths, which we are just in the beginning of exploring so far. Imagine someone who writes on the application of different methods in a self- 
descriptive mode. She/he unfolds different methods as she/he goes along and uses them, describing the exact sequence of operations, reactions, surprises, difficulties and the like. "The strongest form of a self-generative description is organized in a recursive way. In the case of the writing of the application of different methods and a group of users who follow these self-descriptions and who report on their problems and difficulties, preferably not necessarily in a self-descriptive mode, too. These reactions, then, lead to a revision of the original text, once again in a self-descriptive manner. This process can be organized recursively, round and round until an eigen-description has been reached" (Ibid: 105).

13. Self-Writing Theories: This road is of a theoretical nature and could be conceived of as a brain writing the story of a brain. The self-writing of a theory of the brain of an observer follows a far more restrictive design than in the first cluster of re-entering theories or in the second cluster of selfinclusive observers. Here, a theory of the brain, constructed by an observer, must emerge in the process of describing the cognitive operations in writing such a theory. "Thus, the process of theory construction must be conducted in very a strong self-referential manner where a theory of the brain unfolds in the process of writing about its unfolding" (: 106).

14. Self-Designing Designs: Finally, the last road to self-reflexive research designs arises, almost naturally, in the domain of research-designs themselves and can be characterized as a dual re-entry of both domain and observers into the domain of origin, namely into the domain of research designs. This process can be re-iterated, in principle, to the point of writing a research design about research. 